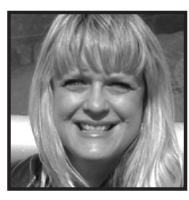

\title{
Con Aprecio / With Appreciation: Pushing Beyond the Boundaries of Possibility in Educational Professional Development
}

\author{
M. Cathrene Connery, Central Washington University
}

\begin{abstract}
The need for relevant, continuous, and restorative professional development is evident at all levels of teacher education. As teachers teaching teachers and educators educating educators, we aspire to implement meaningful, sustaining, learning experiences that make a difference in the lives of children, families, educators, and communities. This reflective testimony calls us to consider the funds of knowledge and example of our colleagues in the tireless quest to embody and enact civil rights law, and move beyond the boundaries of possibility in educational professional development to actualize educational equity and social justice.
\end{abstract}

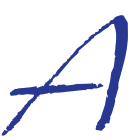

s a professor anxiously awaiting the modifications to and reauthorization of the United States' Elementary and Secondary Education Act (2002), I spend a lot of time thinking about the role of professional development in the lives of my teacher education students and public school colleagues. The need for ethical, intelligent, and relevant professional development is especially important for administrators in higher education who are insulated from the realities of economic insecurity, K-12 classrooms, and the tenure process. As teachers teaching teachers and educators educating educators in positions of power and privilege, it is our obligation to implement meaningful, sustaining, learning experiences that will ultimately make a difference in the lives of children, families, teachers, and communities. However, when I reflect on the value and impact of the various meetings, classes, workshops, trainings, sessions, seminars, retreats, conferences, graduate degree programs I have attended 
across my professional career, I return full circle to a basic truth: Everything I needed to know, I learned from my bilingual teaching assistant.

When I first noticed Aleta in the hallway of our elementary school, she was indistinguishable from the kids. Like her indigenous ancestors, she stood at a slim, yet compact, five feet tall. Balancing a tub of manipulatives against her right hip, Aleta's most identifiable characteristic was the river of dark chocolate hair that extended past her torso. She would sometimes braid it into a plait that cascaded and bobbed down her back, calling attention to the tiny gold earrings that delicately framed her café-conleche complexion.

Aleta was a natural beauty without knowing it; below the curl of her bangs, her thoughtful, doe-like eyes wisely took in her surroundings. Most the time, she wore her tresses on top of her head, swept swiftly from her waist in a single movement to be expertly secured in place with the dart of a pin and a raised eyebrow. When we first worked together in the American Southwest during my late twenties, she was chronologically 10 years my younger, yet already my senior and mentor. A portrait of the tireless pursuit of civil rights law, Ms. Aleta Nuñez ${ }^{1}$ pushed me to develop myself, our students, and many others to move beyond the boundaries of possibility in educational professional development to actualize educational equity and social justice.

The squared edges of the plaque poked through the white tissue paper. As she handed it to me, she said to open it later. She knew I would cry, and it was not her way to have an emotional goodbye. In fact, I don't think we ever acknowledged I was leaving for doctoral studies. Later, when I opened her present in the shadow of the mountain, I choked back the tears. The words on the wall hanging read: "Con aprecio. Tu me has conmovido. Yo he crecido." In the eight years we had worked together, she had never given me a material gift; her family was trying to save enough money for a house to raise their children in on the pittance she earned. The words on the plastic wall plaque captured my heart, for until that moment, I hadn't really known what I had meant to her. They read: With appreciation. You have motivated/moved/inspired me, and I have grown.

Aleta was born in 1973 on a January day when the snows on the mountain glitter against the sky. She took her place in a long line of pioneers who transcended geographic, sociocultural, and ideological borders, to represent the best of the human spirit. Like many Norteños who traveled the roads of Aztlán, her antepasados migrated back to where the mighty Colorado runs red in canyons, never losing touch with their Mexican homelands (Rosales, 1996). 
True to their Spanish heritage, Aleta's ancestors taught the Americanos how to be cowboys when rural Chihuahua burned dry in the summer sun. By the 1950s, the Nuñez menfolk had earned a reputation for skilled work and dependability among Anglo farmers, miners, and ranchers in a tiny mountain town, settling as the first Latino family among 400 residents. At a time when Hispanics were denied access to local institutions and businesses, los Nuñez drew on their internal resources, establishing their home among cottonwood trees (Rosales, 1996).

Aleta's father came of age during the 60 s when hippies and celebrities discovered the recreational possibilities of the region. Like his padre and his father's father before him, Juan was a ranch hand with a quick wit. His good looks, modales perfectos, and honest speech rendered him a serious candidate for marriage. His bride Veronica, la mitad de su naranja, a graceful and warm woman, would intelligently and humbly raise his three brown-eyed children. As the 60 s turned into the 70 s, their immaculate home was accompanied by the trailers of other relatives and paisanos who could not make a decent living in the cuidades perdidas or Mexican hinterlands (Rosales, 1996).

As the farms and mines shut down, the extended Nuñez family and their neighbors joined the growing number of immigrants building and cleaning resort homes for an influx of celebrities and wealthy business owners. In time, their pastoral community would be eclipsed by a dramatic and enduring economic shift from an agricultural to a tourist industry. Without a solid academic education in the English language, increasing numbers of Spanish-speaking braceros and service workers were forced to compete with the hippies-turned-yuppies and seasonal workers brought in by multimilliondollar ski corporations. The rise of technology in the 1990s would give license to a land grab among the super-rich, real estate agents, and lawyers, resulting in a temporary building boom, exorbitant housing prices, and the whole-scale relocation of workingclass families downriver, with significant impacts on the Nuñez and their neighbors.

Shortly before Aleta's birth, the U.S. Office of Civil Rights in Washington D.C. issued a memo to public school administrators in her state reminding them that Title VI of the Civil Rights Act of 1964 outlawed discrimination and the denial of academic services to students ${ }^{2}$ on the basis of race, color, or national origin (Crawford, 2004). The 1970 memorandum was followed by Title IX (1972), ensuring gender equity in every educational program receiving federal funding. These affirmative steps, and the Supreme Court's ruling in Lau vs. Nichols (1974) obligating all American schools to implement the instructional means to learn English, were ignored by the district in the developing mountain valley. 
When Aleta turned one and a half, the future of the Nuñez family was changed by the stroke of a presidential pen signing the Equal Educational Opportunities Act (EEOA) in 1974. Across the United States, school desegregation had been largely unsuccessful. Standing on the 14th Amendment, the EEOA (1974) irrefutably entitled all public school students to an "equal educational opportunity without regard to race, color, sex, or national origin," establishing the standard for school placements to be the most appropriate neighborhood school. The law also outlawed discrimination against school staff and faculty members, including para-educators, teacher assistants, teachers, and administrators. Schools that exhibited a "failure ...to take appropriate action to overcome language barriers that impede equal participation by its students in its instructional programs" were explicitly breaking federal law.

For the first time in U.S. history, Aleta and other linguistically and culturally diverse children had the legal right to attend the same schools as their European-American, English-speaking counterparts (Donato, 1997; Ruiz, 1997). Children who previously traveled extended distances to attend school could enroll within a few blocks or miles of their homes. Principals and teachers were prohibited from mis-educating or harassing students by placing them in unsuitable classrooms, grade levels, or instructional programs. Passage of the EEOA (1974) ensured academic language support so nonnative English learners might understand their teachers and access the curriculum (Crawford, 2004). The law also meant Juan and Veronica could send their three children to school and expect them to be treated with respect.

When Aleta began kindergarten in 1978, Veronica would brush her daughter's long hair, preparing her hija for the coming day. With each soothing stroke, mother and child would problem-solve about the decisions Aleta would make and behavior she would choose as a representative of the family name. Her mama would tell her that la familia depended on her to bring English home from school. She carried her parents' strong sense of morality, initiative, and tenacity into the classroom. Teachers described Aleta as an eager, curious, and focused student, who rarely missed a day of class. A thoroughness and efficiency characterized her actions. At home, she ironed perfect creases into her father's and brother's cotton shirts, once explaining that a real Mexicana would never allow her menfolk to wear anything but perfectly pressed shirts. At school, Aleta steadfastly persevered to master literacy and numeracy in her second language, while acquiring reading and writing proficiencies in Spanish at home. Without Title IX, she could not have developed the same fierce intelligence, strategy, and determination on the basketball court and soccer field. Aleta grew into a serious, stunning young woman, who communicated through a thousand calibrated smiles that revealed a horizon of ivory teeth. 
When Aleta dropped out of school at 16 to get married and start a family, her teachers and a principal parked under the cottonwood tree, rapped on the door to the trailer, and convinced her inside the small living room to finish her studies. In 1990, she graduated at the age of 17, just before her first child was born. The greatest riches of her life continued to be found in the arms of family. Her husband was a mechanic who could fix anything. One day on the job, a piece of equipment became stuck in the earth and Pedro was permanently disabled while trying to remove it under his supervisor's orders. When the employer contested his claim for Workman's Compensation, his paycheck, body, and career were unjustly sacrificed for a bracero only in his 20s. After the accident, Aleta's family relied solely on the income generated from her many talents. Carolín, their eldest, loved to follow her mom around and play silly word games that became more sophisticated as she grew older; by the time Junior was four, he could name every dinosaur in Spanish, English, and Latin. Mechita and Priscilla would come later, all beautiful, vibrant, intelligent children, bringing their mother great pride in equal and yet diverse ways, grown in the sunlight of love with high expectations.

In 1990, Aleta also began her teaching career as a bilingual education assistant during which I was privileged to learn from her for eight years. Carolín's birth motivated Aleta's transition into college, whereby she immediately began working on a Bachelor's degree in Education. Slowly, steadily, mindfully, she whittled away at her coursework. We teamed together sharing first and second grade English as an Additional Language students, and co-taught in our Spanish-English, dual immersion, fourth and fifth grade classrooms. We exulted in our students' successes, struggled against their hardships, grieved their losses, and breathed in with satisfaction their many accomplishments as comadres. Laughter bound our respect for each other. My bilingual assistant taught me how to be a teacher.

The pencil Aleta poked into her bun while teaching a morning reading group would be pulled out as a pick-axe at lunch to chip away at her homework. After her children and husband went to bed, she would fall asleep over her textbooks. One summer, we enrolled in a graduate course with a well-known bilingual education researcher. A fellow Latina, she threw Aleta out of her class in the first 10 minutes for not yet completing a Bachelor's degree. We exited her classroom together in disgust.

Undeterred, purposefully, and successfully, Aleta earned her B.A. and initial teaching certification as well as a Master's degree, serving the profession for 22 years as a teacher's aide, an elementary classroom teacher, a high school Spanish and EAL educator, a soccer coach, and an EAL and General Education Diploma (GED) community college professor. In a reversal from early conversations, she took on the role of surrogate mother for her 
own students, both inside and outside the classroom, challenging them to never forget their Spanish or be ashamed of where they were born. Aleta carried the same powerful message as a founding member of a group of diversity trainers, seeking to cultivate student agency and leadership within diversity-responsive school networks, to combat prejudice and other forms of violence.

Aleta's commitment to the greater good of all children, Hispanic and Anglo, was unswerving. She advocated for their healthy growth and development, envisioning school as a safe, happy, and just harbor. In 1990, the number of Spanish speakers in our community had increased dramatically-and would continue to do so well after my departure-until EALLs comprised over $60 \%$ of the students enrolled today. If the Civil Rights Act (1964), Title IX (1972), and the EEOA (1974) shaped Aleta's destiny, the measures outlined in Castañeda v. Pickard (1981) would define both her professional practice and advocacy efforts: our school and district were portraits of non-compliance, and Aleta labored-often at great personal expense-with a small group of allies to effectively implement "English language services or programs" "based on sound educational theory" to children legally entitled to them.

According to the ruling, American school districts could not place English language learners in the back of a classroom and expect them to passively learn the language by osmosis (Crawford, 2004). In company with all other U.S. schools, districts became/ were/are required to legally identify non-native English speaking students when enrolling children. The tiny audio-visual storage and stifling pipe closet where Aleta exclusively taught Latino/Chicano-American citizens and Mexican national students could no longer / cannot be designated as an appropriate or safe instructional space. After the Castaneda (1981) ruling, materials and resources needed/need to be ordered to actually implement a curriculum. Our district, and all other American schools, was/were/are responsible for hiring sufficient numbers of qualified faculty whose responsibilities included/include monitoring program effectiveness. Students could not / cannot be exited too early or too late from English as an Additional programs and never without parental consent. The law required/requires oral interpretation and written translation - at the expense of the district and not the families - to inform parents and caregivers about important school information including report cards and other documents. EALLs could not / cannot be denied access to special education testing in their native language or services including gifted and talented programs.

While she would never admit it, Aleta was perfectly posed for advocacy. She was a living example of the Spanish word for "educacíon"; her demeanor and comportment were always wise, considerate, and gracious. She was polite to everyone and would 
work with and learn from them if she could. But Aleta didn't owe anyone anything; her loyalties were aligned with civil rights and educational law and, ultimately, what was best for a child's future development. Consequently, her respect needed to be won and maintained. On occasion, she forced me to confront my own professional incompetencies, terrors, and oversights when, as an emerging Spanish speaker, I was afraid to miscommunicate with parents on the phone. Her intentions were never to humiliate or hang anyone out to dry, but she held high expectations for everyone to continue to develop professionally.

Once admitted into Aleta's circle of trust, a witty observation or simple statement of truth instantly lit up her bright, intelligent eyes like a sudden sunburst on a windy day. She was generous with praise or support when warranted or needed. She ignored her exclusion from co-workers' parties, weddings, and baby showers, and disregarded chatter about inexpensive vacations to Acapulco. She was the friend I called when colleagues were cruel, and the sister I didn't have going through the death of my mother and brother. When her own happiness was confronted by existential dilemmas, Aleta's ultimate solution was to apply the common denominator of unity. This value sometimes resulted in loneliness and suffering, but Aleta walked with a clear mind and heart in accordance with her principles.

Looking back, I see Aleta taught me things that are reflected in my everyday life and professional practice some 20 years later. She taught me to place the avocado pit into the bowl to keep guacamole from turning brown. To salt the egg pan from breakfast so the kitchen won't smell like sulfur after work. To always wait for mothers who were late to conferences in case they were on foot and always taste dishcloth-wrapped tortillas directly in front of the gift-giver. When writing letters home to parents/caretakers, Aleta advised to use "estimado" instead of "querido," unless I wanted to provoke all kinds of curiosity or drama. She taught me to smile before November because the complexities of emotion and scourge of racism can ravel the braid of language and content acquisition. Aleta wisely pointed out that learning can only take place when it is gently pushed beyond boundaries that exist within a compassionate relationship secured by high expectations.

She educated me about the lives and histories of the children we taught, insisting that although families may be challenged by poverty, their days were abundant. Aleta noted that the wealthy weren't necessarily rich, nor the privileged favored. She ascertained being thirsty for kindness was a form of drought. She demonstrated that the greatest gifts a teacher could deliver were lessons in confidence and edified that social justice is achieved on a daily basis in our everyday engagements with each 
other. Aleta rarely uttered dichos out loud; instead, she lived her practice fully, clearly, and comprehensively with grace, optimism, and pride.

Pushing beyond the boundaries of possibility in educational professional development, as Aleta so aptly espoused, is especially important at this moment in history for several reasons. First, as American legislators seek to replace the ESEA's "No Child Left Behind Act" (NCLB) (2002) with the "Every Student Succeeds Act," how can we truly prepare all of our children for a future without cultivating and extending our diverse and collective sociolinguistic heritages? The outgoing law completely cut out earlier renditions of the bill funding multilingualism and bilingual education. In a sweep of educational rhetoric, NCLB (2002) eradicated the biliterate, academic needs of all American K-12 students, while jeopardizing the United States' global standing within diplomatic, academic, scientific, business, and cultural circles. Without the mindful, systemic, and systematic cultivation of linguistic expertise beginning in kindergarten, we tongue-tie and restrict our abilities to individually, communally, and collectively address the societal problems that threaten us. Will American legislators have the foresight to pass a law that that places the 21st century proficiencies of multilingualism and biliteracy within the reach of all children as future global citizens?

Second, one out of every five children in the United States is currently growing up in poverty, with children representing the poorest demographic in the country (U.S. Department of Commerce, 2015). These students represent over $51 \%$ of all children enrolled in American public schools, with English Language Learners comprising over $40 \%$ of this same demographic (NCES, 2014). As biliterate potentials, EALLs are not only national resources, but also prospective treasures. Despite the codification of equal educational opportunity based on sex, race, and national origin, issues of academic inequities persist, especially with respect to gender, socioeconomic status, and language. By federal law, all children in the United States warrant an equal, equitable, and enriched education. As Aleta's family history attests, these codes are living, breathing forces impacting our daily lives and collective futures. Will American legislators have the foresight to pass a law that authentically challenges or combats circumstantial and intergenerational poverty?

Third, NCLB (2002), like other legislation of its time, banished common sense, scientific research, and democratic values from classrooms, flinging public school doors open to private enterprise and personal profit. While other markets faltered, the corporate hijacking of the curriculum instituted a sorting system dependent on digital access and linguistic competencies. The engorgement of Big Media, through the computer and testing industries, have not only left children behind, but also 
banished them from standing at the gate. Will American legislators have the foresight to pass a law that protects the learning spaces of children from exploitative and predatory businesses?

To push beyond the boundaries of possibility in educational professional development, we must stop and reverse such intellectual, cultural, and creative lossesfar more serious than the GDP - to re-implement a linguistically and developmentally appropriate vision of childhood. Pushing beyond the boundaries of possibility in educational professional development actively rejects the colonization of privilege through corporate standards that fly in the face of mindfully developed bodies of thought based on scientific evidence. It demands that we rescue schooling from congressional and legislative committees devoted to big business and the defense industry, by placing a free, equal, and enriched education back between the national pillars of health and human welfare where it once resided (Crawford, 2004)

Pushing beyond the boundaries of possibility in educational professional development obligates us to hold accountable those educators and policy makers whose daily complicity or weak compromises place them morally, ethically, or legally above the law. It solicits us to restructure and retool programs that are equally good for the rich and the poor, without placing the expense onto indigenous, dual-language, transnational, or refugee learners. Pushing beyond the boundaries of possibility in educational professional development demands that we re-conceptualize schooling and teacher education as the opportunity to co-create critical, creative, and linguistically rich pedagogies that engender sustainability with the expertise of our community partners. In order to achieve these goals, we must move beyond false professional development experiences that allege to present the real-life narratives and perspectives of individuals who have been marginalized from the protection and pretension of academic bubbles. We must dignify the contributions of our bilingual teaching assistants and students while consciously and actively respecting and advocating on behalf of their real-life experiences, linguistic expertise, and occupational potential. Nuestras comadres would call it love with high expectations.

Aleta was diagnosed with kidney cancer in 2012, an injustice for a woman who had never smoked a cigarette or drank alcohol. Her students and staff shaved their heads, raising money for her treatment; a former principal donated a plethora of sick days so she wouldn't lose her job in between surgery, chemotherapy, and radiation. But the cancer spread to Aleta's lungs. She tried experimental drugs without success. When I flew in to see her at Thanksgiving, her wise eyes still shone. She dragged her oxygen line from the bedroom to the kitchen table, so we could sit and talk awhile. 
She unconsciously ran her hand back and forth over her bald head. "Are you afraid?" I asked. Her chin moved from right to left and then back again. "I'm not afraid for myself," she replied. "But I fear for my kids," and, very quickly, turned it away.

Aleta died in 2013 on a December day when the snows on the mountain glittered against the sky. She was 40 years old. She is survived by her grandmother, both her parents, a sister and a brother, her four children, two grandbabies, and her many aunts, uncles, cousins, nephews, nieces, students, and colleagues. She was buried on the side of the mountain overlooking the valley and the tiny square schools and soccer fields where her chocolate braid bobbed down her back as she ran. For the last 20 years, her plaque has hung in my many offices, strategically placed as a reminder for me to develop professionally every single day, sending out its simple, elegant, and reciprocal message:

The squared edges of the card poked through the white envelope. As I handed it to her, I said to open it later. I knew she would cry, and it was not her way to have an emotional goodbye. This time, we both knew she would be leaving, for the cancer had spread to her brain. "We love you, Cata," affirmed her mother in Spanish as the family walked me to the living room door. A few minutes later, I pulled over, faced the mountain, and choked back the tears. She would read that she had captured my heart and had meant the world to me: "With appreciation. You have motivated/moved/inspired me, and I have grown.

Let us do right by Aleta and all our children. May Americans love and hold their legislators to high expectations. Together, we must push beyond the boundaries of possibility in professional development to actualize educational equity and social justice.

\section{Notes}

1. A pseudonym: The author wishes to thank Aleta's family for permission to publish its history.

2. For more information about the civil and educational rights of linguistically diverse students and their teachers in the United States, see the U.S. Department of Education's Office for Civil Rights at: http://www2.ed.gov/about/offices/list/ocr/ index.html 


\section{References}

Crawford, J. (2004). Educating English learners: Language diversity in the classroom (5th ed.). Los Angeles: Bilingual Education Services.

Donato, R. (1997). The other struggle for equal schools: Mexican Americans during the Civil Rights era. New York: State University of New York Press.

Kena, G., Aud, S., Johnson, F., Wang, X., Zhang, J., Rathbun, A., et al. (2014). The Condition of Education 2014 (NCES 2014-083). U.S. Department of Education, National Center for Education Statistics. Washington, DC. Retrieved from http://nces.ed.gov/ pubsearch.

Rosales, F. A. (1996). Chicano: The history of the Mexican-American civil rights movement. Houston, TX: Arte Publico Press University of Houston.

Ruiz, R. (1997). The empowerment of language-minority students. In A. Darder, R. Torres, H. Gutierrez. Latinos and education: A critical reader (pp. 319-327). New York: Routledge.

Suitts, S., Barba, P., \& Dunn, K. (2015). A New Majority: Low Income Students Now a Majority in the Nation's Public Schools. Southern Education Foundation. Retrieved from www.southerneducation.org.U.S. Congress. (1964). Public Law 88-352. The Civil Rights Act. Retrieved from http://www.gpo.gov/ fdsys/pkg/STATUTE-78/pdf/STATUTE78-Pg241.pdf
U.S. Congress. (1972). Title IX of the Education Amendments of 1972. 1681-1688. Retrieved from http://www.justice.gov/crt/title-ix-edu cation-amendments-1972

U.S. Congress. (1974). Equal Education Opportunities Act (1974). 20 U.S.C. §1203(f).

U.S. Department of Commerce. (2015). Poor Children (under age 18 and under age 5), number and percent: U.S. Department of Commerce, Bureau of the Census, Current Population Survey, 2015 Annual Social and Economic Supplement, Table POV01 (Below 100 percent of poverty, all races).

U.S. 5th Court of Appeals. (1981). 648 F.2d 989 Castañeda v. Pickard. (1981) Retrieved from https://scholar.google.com/scholar_case? case $=16848723757397550913 \& q=$ casta neda+v.+Pickard\&hl=en\&as_sdt=6,48\&as_ vis $=1$

U.S. 107th Congress. (2002). Public Law 107-110. Elementary and Secondary Education Act: No Child Left Behind. Retrieved from http:// www2.ed.gov/policy/elsec/leg/esea02/107110.pdf.

U.S. Supreme Court. (1974). Lau v. Nichols, et al. No. 72-6520. 
M. Cathrene Connery is a Senior Lecturer in the Language, Literacy, and Special Education Department at Central Washington University. A bilingual educator, researcher, and advocate, she has presented, written, edited, and consulted nationally and internationally on theoretical, pedagogic, and programmatic concerns surrounding the education of culturally and linguistically diverse children in the United States for the past 30 years. Dr. Connery's writing has explored Vygotskian or cultural-historical approaches to language, learning, and pedagogy, including Profiles in Emergent Biliteracy: Children Making Meaning in a Chicano Community (2011) and Vygotsky and Creativity: A Cultural-historical Approach to Play, Meaning Making, and the Arts (2010; 2016). 